sciendo Порівняльна професійна педагогіка 8(4)/2018 Comparative Professional Pedagogy 8(4)/2018

DOI: $10.2478 /$ rpp-2018-0049

PhD in Pedagogy, Associate Professor, ANDRII BALENDR

Bohdan Khmelnytskyi National Academy of the State Border Guard Service, Ukraine

Address: 46 Shevchenko St., Khmelnytskyi, 29000, Ukraine

E-mail: drbalen@i.ua

\title{
CURRENT STATUS AND PROSPECTS FOR THE QUALITY ASSURANCE IN BORDER GUARDS TRAINING: EUROPEAN EXPERIENCE
}

\begin{abstract}
The article reveals the current status of the quality assurance development in the training process of the European Union (EU) border guard agencies. Besides, the study aims to describe the prospects for further quality assurance development of the border guards training in the EU countries. The views of scientists on the concepts of "quality assurance and control" and "quality of training" were critically studied. The quality of a border guard's training was defined as a set of knowledge, skills and competencies of a border guard, including a border guard's personal qualities, characteristics, which define a person as a specialist in the sphere of the state border protection and distinguishes him or her from other specialists and ensures success along the border guard career path. The study of the quality assurance system of border guards' training in the EU countries revealed that it is conducted by the European policies and educational and training standards and promotes the formal certification and external accreditation of border guards' training. It is indicated that the prospects for developing quality assurance mechanism for all-European border guard courses are connected with the possibility to provide external accreditation for such courses as: Introduction to Educational Technology and Training Delivery Methodology, which the author completed in 2017 and 2018. The process of accreditation is being conducted by an international quality assurance agency. The quality assurance system of the border guards training in EU is used in the Joint European Master's Program in Strategic Border Management, developed by FRONTEX Agency in cooperation with European educational establishments. So, the State Border Guard Service of Ukraine can be particularly interested in this program, in order to facilitate the increasing of quality of Ukrainian border guards training.
\end{abstract}

Keywords: quality assurance, border guards training, European Union countries.

\section{INTRODUCTION}

Today, the process of reforming the law enforcement agencies of Ukraine, which also includes the State Border Guard Service of Ukraine (SBGSU), determines the further development of the Ukrainian border guards training system. This requires careful study of the European standards for the border guards training, which puts forward implementation of the quality assurance mechanisms used in the European Union (EU) border guard authorities.

Quality assurance of education and training is one of the main preconditions for mobility, compatibility and attractiveness of the education system of any country. Promoting European cooperation in the sphere of education quality assurance is a requirement of the Bologna process. In world practice, there are different approaches to assess the quality of the educational establishment work: reputation-based (using experts' 
assessments), result-based (using objective indicators) and general one. The task of ensuring the quality of education is multifaceted and includes the availability of necessary resources (human, financial, material, informational, scientific, educational, etc.), organization of the educational process that should correspond to the current trends in the development of national and world economy and education, control of educational activity and the quality of training specialists at all stages of education and at all levels: educational institution level, national level and international or European level (Yakymenko, 2005).

Nowadays, in the sphere of border protection the importance of improvement of the quality assurance for the personnel training involved in border control on the EU external borders, along with increasing pressure of illegal immigration and threat to border security of the EU member states, the requirements to border guards' professionalism and ability to operate in a multinational environment are tightened (Zalitis, Zukova, \& Madzule, 2016).

Thus, the problem of quality of border guards training requires solving of a number of tasks to ensure the preparation of a border guard with high moral aspirations and motives, who will be socialized, mobile, ready to perform service duties in challenging and controversial circumstances.

\section{THE AIM OF THE STUDY}

The aim of this article is to analyze the current status of the quality assurance development in the training process of the EU border guard agencies. Besides, the study aims to describe the prospects for further quality assurance development of the border guards training in the EU countries.

\section{THEORETICAL FRAMEWORK AND RESEARCH METHODS}

The need for increasing the quality of border guards training requires addressing the problem of enhancing professional training on the basis of foreign experience, in particular what concerns quality assurance. Problems of quality assurance of specialists' training in international educational space have been studied by both Ukrainian and foreign scholars: the European educational standards (Bidiuk, 2018); challenges to European border guards' educational quality assurance (Zalitis, Zukova, \& Madzule, 2016); implementation of the Sectoral Qualifications Framework for Border Guarding (Peres, \& Norris, 2017); the practical issues of the border guards' training (Balendr, 2018; Bloshchynskyi, 2017). The peculiarities of quality assurance development were considered in such key EU documents as: Declaration of the European Ministers of Vocational Education and Training ("Copenhagen Declaration”); European Qualifications Framework for lifelong learning (EQF-LLL); Council Recommendation on the validation of non-formal and informal learning; Bordeaux Communiqué on enhanced European cooperation in Vocational Education and Training; Bruges Communiqué on enhanced European Cooperation in Vocational Education and Training for the period 2011-2020; Council conclusions on quality assurance supporting education and training.

In the sphere of border protection first of all should be mentioned development and introduction of the Sectoral Qualifications Framework for border guarding (SQF), Common Core Curricula for basic, mid and higher border guard education. In order to accomplish the tasks of the article the following methods were used: critical and logical analysis of pedagogical and quality assurance literature; comparative study of the basic concepts, trends in quality assurance sphere; pedagogical observation, collection and generalization of data, analysis of EU legislation and policies in the sphere of vocational education and training.

In order to identify the main problems of ensuring the quality of the border guards' training, the views of scientists on the concepts of "quality assurance and control" and "quality of training" were critically studied. 
sciendo Порівняльна професійна педагогіка 8(4)/2018 Comparative Professional Pedagogy 8(4)/2018

The International Organization for Standardization has adopted the following definition of quality: "Quality is a set of characteristics of an object that relate to its ability to meet established and foreseeable needs". Quality assurance and quality control are two aspects of quality management. While some quality assurance and quality control activities are interrelated, the two are defined differently. According to ISO 9000:2015: Quality assurance consists of that "part of quality management focused on providing confidence that quality requirements will be fulfilled". While quality assurance relates to how a process is performed or how a product is made, quality control is more the inspection aspect of quality management (ISO, 2015).

Achievement of quality characteristics depends on management, which ensures their values, complex and combination. Quality is considered not only as a result of activity, but also as an opportunity to achieve it in the form of internal potential and external conditions, as well as the process of formation of characteristics (Korotkov, 2006).

The concept of "quality" is a philosophical category that "... expresses the internal certainty of an object that is a specificity that distinguishes it from all others" (The Great Explanatory Dictionary of Modern Ukrainian Language, 2001). According to O. Subetto (1989), the quality of training of specialists is an integral indicator of the state of education and the level of knowledge of students. Concerning the concept of "quality of a specialist training", the modern science uses a variety of interpretations. It is understood as a set of properties that allows to perform skilled professional work in accordance with the passport of a specialty, take an active civil position, constantly improve one's qualifications, and allows to change the profession later (Suslov, 2005).

The researcher I. Kanivets considers the quality of a specialist as an objectively existing set of properties and characteristics (knowledge, abilities, skills, personal qualities), which defines a person as a specialist in a particular profession and specialty and distinguishes him from other specialists. The quality of training of a specialist, in the opinion of the researcher, is a set of essential properties and characteristics, the level of which is formed in the process of educational activities and must meet the requirements of consumers. (Kanivets, 2004).

Consequently, there are different views on the concepts of "quality of a specialist training". There is an international quality management experience - the system of total quality management. The use of this system is possible only taking into account the peculiarities of educational processes and the conditions of modern national pedagogical management. The quality of education can reflect today's needs, but may be aimed at the future. It is necessary to ensure quality, taking into account the development of trends in education (Korotkov, 2006).

So, the concept of "border guards' training quality" can be formulated as a set of knowledge, skills and competencies of a border guard, including his or her personal qualities, characteristics, which define a person as a specialist in the sphere of the state border protection and distinguishes him or her from other specialists and ensures success along the border guard career path.

\section{RESULTS}

Speaking about the personnel training in the EU border guard agencies nowadays, FRONTEX Agency (European Border and Coast Guard Agency, in order to facilitate the increasing of quality of the EU border guard training, initiated the Quality Assurance project. The aim of the project, which was started in 2017, is to develop a quality assurance system for the EU border guard agencies that would be aligned with the European policies, 
standards and best practice in vocational education and training, enabling the formal certification and international recognition of FRONTEX training. The ultimate goal is to ensure that operational competencies are achieved in all border guard training activities and that the border guard agencies of EU and Schengen associated countries receive best value from professional, quality assured training (Peres, 2017).

FRONTEX uses the European fundamentals, standards and guidelines for quality assurance applicable to vocational education and training across EU and recognizes that defined policies and procedures must be in place to ensure a coherent approach to quality assurance of FRONTEX programmes, courses and curricula and the quality assurance of the EU Member States and Schengen Associated Countries training (Quality Assurance Policies and Procedures, 2017).

In the sphere of border guards training quality assurance applies risk-based thinking to anticipate what can go wrong and take all measures necessary to help the situation. A key concept in quality assurance of vocational education and training according to Council Recommendation in Vocational Education and Training is the Plan-Do-Check-Act cycle, also known as "the Deming cycle" named after its inventor W. Deming. It is quite a common sense concept that underlines the continuous nature of quality improvement, which starts with planning and improvement, implementing it, checking if the improvement has happened and acting further on the outcome to initiate a new improvement cycle. It involves strategic planning, goal setting and definition of standards, continuous monitoring and analysis of factors contributing to quality, measuring the results according to predefined goals, and managing change in the view of the achieved results (Peres, 2017).

Quality assurance in border guard organizations allows recognizing and validating the great amount of on-the-job training (OJT), which takes place every day at the border. It can become possible to rely not only on people's degrees and diplomas to assess their competence, but also to assess and validate their operational learning and experience on the job. FRONTEX trainers can be accredited and formally recognized as FRONTEX certified trainers with the help of external accreditation. The implementation of quality assurance system brings international reputation of excellence to EU border guard training. The diplomas received as a result of such training will be recognized worldwide like any other university diploma.

FRONTEX fulfils its training mission by providing education and training for border guards in the EU Member States and Schengen Associated Countries, aligned to the Bologna and Copenhagen processes and the EQF. As an overarching frame of reference for all border guard education and training, FRONTEX Agency elaborated the SQF.

The SQF is a platform for a coherent strategy that links all training products and contributes to the harmonization of border and coast guard education and training. It supports the national integration of all common curricula, as it offers specific reference points for all border guard learning requirements, consistent and aligned with the EQF. The SQF is thus ensuring comparability of qualifications and creating the premise for the recognition of learning in all its forms - formal, informal and non-formal. For FRONTEX, the SQF is an instrument for reviewing training and for quality assurance that will lead to the development of courses that can be accredited (Quality Assurance Policies and Procedures, 2017).

One of the functioning models of quality assurance system in the sphere of border guards training is a Joint European Master's Program in Strategic Border Management (EJMSBM), which FRONTEX developed in collaboration with several European Universities and Academies, as an innovative transitional joint degree. 
Originating from the border guard community and developed in collaboration by border guards and academics from over $20 \mathrm{EU}$ countries, the EJMSBM is designed as a programme where the learning has practical application for the EU border guard organizations which are the ultimate beneficiaries. The programme is completely learner-centered focusing on the relevance of the learning requirements for operational competence. The programme is delivered over 3 semesters of 30 ECTS credits each, with a taught component of 60 ECTS credits comprising 10 modules and a final dissertation stage. Each module is delivered by a different Academic Partner, in collaboration with a border guard academy that brings in the professional expertise, offering an opportunity for the students to be exposed to the different border management practices at various national external borders in the Netherlands, Spain, Estonia, Latvia and Lithuania (Quality Assurance Policies and Procedures, 2017).

The quality assurance structure of the EJMSBM is represented by the Consortium, creating a "mini-university" - a shared governance structure with distributed roles across the Consortium, ensuring an integrated management of the programme and shared quality assurance responsibilities that aim to demonstrate "unity", not "multiplicity", promoting a "culture of jointness" (EUA, 2006). The Governance of the Consortium rests with an appointed Governing Board which is responsible for the implementation and quality assurance of the programme. It acts as an Academic Council for the programme and it is representative of the Academic Councils of each of the Consortium members, as well as students' representatives. The Consortium also consists of: Program Board, Program Administration, Board of Examiners, Quality Assurance Committee.

The Consortium values the distributed nature of the degree programme and recognizes that a single common set of policies and procedures must be developed and applied by all, to ensure an internally coherent and consistent system in line with each university's regulations, and to offer a harmonious academic experience to the students. All partners implement the quality assurance procedures and cooperate in the quality assurance procedures, sharing responsibilities as defined in the Consortium Agreement (Quality Assurance Policies and Procedures, 2017).

Nowadays the prospects for developing quality assurance mechanism for all-European border guard courses are connected with the possibility to provide external accreditation for such courses as: Introduction to Educational Technology and Training Delivery Methodology, which the author completed in 2017 and 2018. The process of accreditation is being conducted by an international quality assurance agency. The FRONTEX's plans for the future encompass improvement of the quality assurance policies and procedures, gradually extending the quality assurance system to all courses in all spheres, including training of curriculum designers and trainers in design and delivery methodology.

\section{CONCLUSIONS}

The conducted study of the current state of quality assurance system of border guards' training in the EU countries showed that it is built according to the European policies, standards and best practice in vocational education and training, it promotes the formal certification and international recognition of border guards' training in order for all border guards from all EU countries to possess the same, high level of professional competence. One of the operating exemplars of quality assurance system of the border guards training in EU is used in the EJMSBM, developed by FRONTEX in cooperation with European educational establishments. So, the State Border Guard Service of Ukraine 
sciendo Порівняльна професійна педагогіка 8(4)/2018 Comparative Professional Pedagogy 8(4)/2018

might be particularly interested in this programme, in order to facilitate the quality enhancement of the Ukrainian border guards training. in the USA.

Further studies should be related to the quality assurance of border guards' training

\section{REFERENCES}

1. Balendr, A. (2018). Information and communication technologies in foreign languages training of the border guards in the European Union Countries. Information Technologies and Learning Tools, 67 (5), 56-71.

2. Bidiuk, N., Ikonnikova, M., \& Komochkova, O. (2018). Overview of professional education of linguistics students at universities of Great Britain. Advanced Education, 9, 5-10.

3. Bloshchynskyi, I. (2017). Enhancement of cadets' practical training at the National Academy of the State Border Guard Service of Ukraine named after Bohdan Khmelnytskyi. Science and Education, (4), 5-10.

4. European Joint Master's in Strategic Border Management: policies \& procedures. (n.a.). Retrieved from https://frontex.europa.eu/assets_publications/Training/ EJMSBM_Procedures_and_Policies.pdf.

5. European University Association. (2006). Quality culture in European Universities: a bottom-up approach (Brussels, EUA).

6. Kanivets, P. (2004). Modeli i metody otsenki kachestva podgotovki i povysheniya konkurentosposobnosti spetsialistov. (Diss. kand. ekon. nauk). Novocherkask.

7. Korotkov, E. (2006). Kontseptsiya yakosti osvity. Retrieved from http://osvita.ua/ school/manage/general/1342/5.

8. ISO 9000:2015(en) quality management systems - fundamentals and vocabulary. (2015). Retrieved from https://www.iso.org/obp/ui/\#iso:std:iso:9000:ed-4:v1:en.

9. Peres, A., Norris, J. (2017). Sectoral qualifications framework for border guarding the way towards harmonization of border guard qualifications across EU? European Law Enforcement Research Bulletin, (3), 145-158. Retrieved from https://bulletin.cepol.europa.eu/ index.php/bulletin/article/view/289QA

10. Quality Assurance Policies and Procedures. (2017). Frontex - the European Border and Coast Guard Agency. Pl. Europejski 6, 00-844 Warsaw, Poland.

11. Subeto, A. (1989). Kategoriya kachestva i effektivnosti v teorii pedagogicheskikh sistem. Upravleniye kachestvom podgotovki spetsialistov $v$ vysshey shkole. Gorkii.

12. Suslov, A. (2005). Sistema otsenki kachestva podgotovki spetsialista. Kachestvo. Innovatsii. Obrazovaniye, 3, 58-61. Kyiv: Perun

13. The Great Explanatory Dictionary of Modern Ukrainian Language. (2001).

14. Yakymenko, Yu. (2005). Yakist osvity - krok do yevropeyskoyi intehratsiyi. Retrieved from https://kpi.ua/530-3

15.Zalitis, I., Zukova, M., \& Madzule, I. (2016). Quality assurance in border guards' education: challenges and topical issue. Moksliniu straipsniu rinkinys visuomenès saugumas ir viešoji tvarka public security and public order, 17, 290-305. 